\title{
Machines, Masses, and Metaphors: The Visual Making of Industrial Work(ers) in Interwar Luxembourg
}

\author{
Ira Plein
}

In the late nineteenth and early twentieth centuries, monumental steel plants transformed Luxembourg's agrarian countrysides into new industrial landscapes; worker immigration led to the rapid growth of villages into cities; and modern production techniques and rationalization changed the customary rhythms of life and work and created a new demand for a skilled industrial workforce. These were elementary changes, to which the society and the population needed to adapt. Visual representations of the steel industry and industrial work(ers) familiarized society with the rapidly changing environment. ${ }^{1}$ In Luxembourg, as in other industrial countries, images of work contributed to a public discourse that involved industrial companies, policymakers, unions, artists, photographers, and other groups or individuals - all of them deliberately trying to shape the perception of industrial work(ers). These images reflected different perspectives, interests, and agendas, which generated conflicting and continually changing visual representations. The images were published in different media and circulated in the public sphere, contributing to the making of meaning and value of industrial work, the perception of the steel and mining

1 The social institutions that were initiated by the steel industry also played an important role in the self-presentation of the steel industry in Luxembourg. See, for instance, Antoinette Lorang, L'image sociale de l'Arbed à travers les collections du Fonds du logement (Luxembourg: Le Fonds pour le développement du logement, 2009). For earlier examples of the visual mediation of the steel industry in Luxembourg, see Frederik Hermann and Ira Plein, "Envisioning the Industrial Present: Pathways of Cultural Learning in Luxembourg (1880s-1920s)," Paedagogica Historica (2016): 1-17, http://dx.doi.org/10.1080/o0309230.2016.1259243; see also Frederik Herman, Karin Priem and Geert Thyssen, “Körper_Maschinen? Die Verschmelzung von Mensch und Technik in Pädagogik, Industrie und Wissenschaft," Jahrbuch für Historische Bildungsforschung 20 (2015): 47-75; Frederik Herman, "Forging Harmony in the Social Organism: Industry and the Power of Psychometric Techniques," History of Education 43, no. 5 (2014): 592-614.

(C) IRA PLEIN, 2019 | DOI:10.1163/9789004410510_003

This is an open access chapter distributed under the terms of the CC-BY-NC 4.o License. 
industry, and, not least, the image and self-image of industrial workers within Luxembourg society.

This paper investigates visual (re)presentations of industrial work(ers) in the Luxembourg steel industry during the interwar period, drawing on examples in different artistic genres and media, such as film, photography, corporate communications, sculpture, painting, and the graphic arts. As industrial work and a growing proletarian working class were a new phenomenon in Luxembourg society, the topic only slowly entered the visual media. ${ }^{2}$ It was only after World War I and in the wake of major economic, political, and societal changes in Luxembourg that one can speak of a diversity of perspectives and a rising interest in images of industrial work(ers). First, the exit from the German Customs Union forced the steel industry to open up new markets - an undertaking that was supported by commercial propaganda employing mainly photography and film. Second, as the country's new leading economic force, the steel industry became increasingly important for the visual self-presentation of the Grand Duchy of Luxembourg. Third, the evolving working class found its own ways of artistically expressing proletarian perspectives on industrial work and the worker.

By looking at examples in various media, I will analyze the conflicting images and representations of the industrial worker in his immediate industrial environment and in relation to the larger "industrial organism"3; as a

2 The first (and long-running) debate on the steel industry, which can also be traced in the visual media of the turn of the century, related to the Luxembourg landscape. See Ira Plein, "Beautiful Luxembourg, Steel Works, and a Swimming Pool: The Corporate Film COLUMETA and the Formation of a Corporate, and National, Image," in Films That Work Harder: The Global Circulations of Industrial Cinema, ed. Vinzenz Hediger, Florian Hoof, and Yvonne Zimmernamm (Amsterdam: Amsterdam University Press, forthcoming).

3 Biological metaphors were frequently used at the time for various systems, such as the economy, but also for exhibitions. For biological metaphors of the economy in Alfred Marshall's Principles of Economics (189o), see Persio Arida, "Soziale Differenzierung und Wirtschaftstheorie," in Soziale Differenzierung: Zur Geschichte einer Idee, ed. Niklas Luhman (Opladen: Westdeutscher Verlag, 1985), 68-95; for the use of "organische Betriebsgestaltung" (organic business formation) and the "Werkskörper" (corporate body) in the German Ruhr area, see Dagmar Kift, "Die schaffende Menschenkraft bewirtschaften': Zur Schulung und Erziehung von Arbeiter- und Werkskörpern im Ruhrbergbau der 1920er Jahre," in Kontrollierte Arbeit disziplinierte Körper? Zur Sozial- und Kulturgeschichte der Industriearbeit im 19. und 20. Jahrhundert, ed. Lars Bluma and Karsten Uhl (Bielefeld: transcript Verlag, 2012), 73-106; for the biological metaphor in the context of the Gesolei exhibition (1926), see Angela Stercken, "Die Gesolei als Schaubild des Körpers: Sektionen, Überblick," in Kunst, Sport und Körper |GeSoLei 1926-2002, ed. Hans Körner and Angela Stercken (Ostfildern: Hatje Cantz Verlag, 2002), 19-24. The analogy also worked the other way around; see, for example, Fritz Kahn's depiction of the human body as an industrial palace in "Der Mensch als Industriepalast," a poster that 
representative of the industry at large; and as a representative of the working class. To analyze images as visual contributions to a discourse on how to see industrial work(ers), we need to look at what was shown in the images; what specific images and perceptions of industrial work(ers) were constructed and communicated to the audience; and how these messages were defined by authorship, the imaging technology used, and the context of display.

In the deep mines and the magnificent factories, thousands of workers are toiling away at a particularly difficult task. Most of you are only dimly aware of the work done by these anonymous people. They, too, wanted to show you their essential and obscure task. You will visit a mine where you will see the miner's work and the set of tools that he uses to wrest from the soil the precious mineral that is the basis for our national wealth. You will see on the screen the work of the blast furnace worker, the steelmaker, the smelter, the rolling-mill operator, of an entire work world conscious of its value. You will admire the grandeur and the complexity of the industrial organism, where the hand unites with the brain in a harmony that we strive to render as perfect as possible. ${ }^{4}$

These sentences were part of the opening speech that Nicolas Wagner, mining director of the steel company ARBED (Aciéries réunis de Burbach-EichDudelange), gave at the first Luxembourg National Trade Fair in the industrial city of Esch-sur-Alzette in September 1923. Initiated by ARBED director Emil Mayrisch and executed under the auspices of a committee that consisted of high-ranking politicians and industrialists, the ten-day trade fair was designed to showcase Luxembourg's crafts, industry, agriculture, education, vocational training, and social hygiene, as well as the country's history, literature, and fine arts. $^{5}$ Wagner's statement was reinforced by the exhibition's visual presentation of industrial processes and human labor in a variety of media, including

supplemented Fritz Kahn, Das Leben des Menschen, 5 vols. (Stuttgart: Franckh'sche Verlagshandlung, 1926).

4 "Ausstellung der Stadt Esch-Alz," Luxemburger Wort, September 8, 1923, 4. Unless otherwise noted, all translations are the author's.

5 See the exhibition program in the official catalogue Exposition nationale des arts et métiers, du commerce et du travail à Esch-sur-Alzette du 8 au 18 septembre 1923 (Esch-sur-Alzette: Société cooperative, 1923). 
photography, film, and a life-size replica of an ore mine. ${ }^{6}$ A major objective of the trade fair was to promote vocational training and the existing institutions in the field. ${ }^{7}$ Consequently, the mining director explicitly acknowledged and recognized the various industrial trades. At the same time, he emphasized the sublime "industrial organism," where "the hand unites with the brain." From his speech, it is not clear what exactly this alliance of the hand and the brain referred to. From the perspective of the industrial organism, it could signify the smooth and efficient collaboration of the workers (hands) under the supervision of the engineers (brains). With regard to the promotion of vocational training at the trade fair, it could also emphasize the added value of craftsmanship, requiring the coordination of the individual worker's trained hands and skilled brain, which was a core objective of the company's vocational school. ${ }^{8}$ Both meanings would be relevant for the industry's self-presentation, since the skilled worker was seen as an essential element for the functioning of the overarching industrial organism.

These complementary layers of meaning-making - from the individual worker to the overarching industrial organism - can also be found in the industry's visual self-presentation. The mining director's mention of the different professions to be seen "on the screen" most likely refers to (sequences of) the corporate film Columeta, a promotional film produced by Luxembourg's leading steel company ARBED and its subsidiary Terres Rouges in 1921/22, which showed the workers during the various stages of steel production, from the ore mine to the final product. ${ }^{9}$ As the mining director's speech suggests, the film

6 One room at the fair was equipped with a cinema projector to present films on the iron industry. See "Die National-Ausstellung in Esch an der Alzette," Obermosel-Zeitung, September $11,1923,1-2$. The details of the mine replica - the authentic rock formations, real railways and minecarts for transport, timbered chutes, lighting systems, the presentation of drilling methods and the extensive explanations for visitors - were also reported in the press. See "Exposition nationale des arts et métiers, du commerce et du travail," Escher Tageblatt, September 12, 1923, 1; and "Über den Abbau der im Boden lagernden nutzbaren Mineralien," Tageblatt, September 22, 1923, 4-5.

7 The quality of the training was demonstrated and visualized by a competition and a display of craft items made by apprentices.

8 At the Institut Emile Metz, the students were tested in a highly modernist psychophysiological laboratory, in order to determine the occupation most suitable for each candidate. It was precisely this combination of theoretical and practical training that was thought to result in skilled workers. See Herman, "Forging Harmony in the Social Organism"; Karin Priem and Frederik Herman, “'Sensuous Geographies' in the 'Age of Steel': Educating Future Workers' Bodies in Time and Space (1900-1940)" (in this volume).

9 An original full-length version of the film is not preserved. For this essay, I am referring to the reconstructed version of 1997, Vu Feier an Eisen (Of Fire and Iron), published by the Centre national de l'audiovisuel (CNA). The greater part of the film presents the processes of steel 
features the workers as independent motifs, representing the unity of hands and brain in their respective trades. Several scenes communicate different hierarchical ranks within the industrial process. Where the tasks do not require specific skills, the workers are presented as a collective and disciplined workforce, monitored and supervised by foremen or engineers (see fig. 1.1a). In these scenes, it is not the workers but the foremen or engineers who are responsible for the industrial production. ${ }^{10}$ Another scene shows the milling process, with a mill train worker posing in a particularly proud posture, indicating his pride in mastering the huge and presumably dangerous machine (see fig. 1.1b). Tasks that require specific skills or training are occasionally filmed in closeups-sometimes showing the worker as a responsible and qualified collaborator, sometimes cropping the worker's head and focusing on the performance of his "trained hands" (see fig. 1.1c).

The mining director's speech suggests that the film features the workers as skilled craftsmen, representing the unity of hands and brains in their respective trades-a perspective that contributed to the social stratification of the workers on the basis of their vocational training. However, the actual main motifs of the corporate film are not the workers but rather the plants and production processes. Throughout most of the film, the worker(s) must be considered as a subordinate motif, whose predominant task is to be part of a functioning machinery: the industrial organism. Panoramic views and long shots of the industrial sites and plant interiors emphasize the vast dimensions

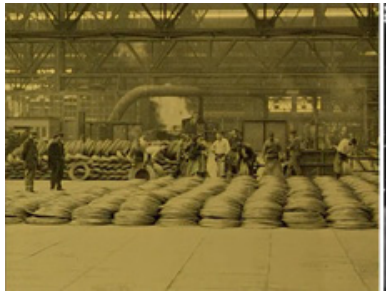

FIGURES 1.1A, 1.1B, AND 1.1C
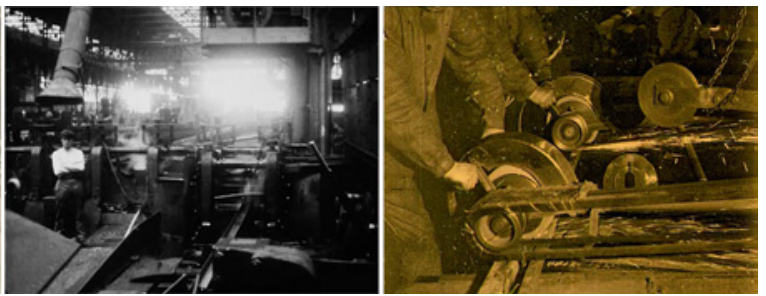

Frames from Vu Feier an Eisen, reconstructed 1997 version of Columeta (1921/22). COURTESY OF CENTRE NATIONAL DE L'AUDIOVISUEL, LUXEMBOURG/ARCELORMITTAL.

production and is framed by scenes of Luxembourg and the sites of production at the beginning and scenes of the industry's welfare institutions at the end. See also Charles Barthel, “'Columeta' ('Vu Feier an Eisen'): L'aventure du premier film publicitaire de l'Arbed," Hemecht 50, no. 2 (1998): 177-206; Plein, "Beautiful Luxembourg, Steel Works, and a Swimming Pool."

10 For depictions of industrial workers' supervision, see also Alf Lüdtke, "Gesichter der Belegschaft: Portraits der Arbeit," in Bilder von Krupp: Fotografie und Geschichte im Industriezeitalter, ed. Klaus Tenfelde (Munich: C. H. Beck, 1994), 67-87. 
and quasi-sublime modernity of the cathedrals of industrialization, where the worker's body only matters as a scale figure (see fig. 1.2a). The camera zooms in on the workers only when the light conditions or the surroundings require it, or if the production processes are shown in detail (see figs. 1.2b, 1.2c). The individual worker (skilled or unskilled) is presented as one among many elements of these production processes. ${ }^{11} \mathrm{He}$ is thus not a distinct motif of the film but presented as a functional part of the overarching industrial organism.

The medium of the "silent" film makes it possible to adapt the film's message to different audiences, highlighting different topics or motifs by, for instance, showing only parts of the film or using different commentaries. ${ }^{12} \mathrm{~A}$ commentary's emphasis on the film's representation of the skilled trades, for example, could serve to promote vocational training. The prominent display of industrial trades at the trade fair could communicate the (skilled) workers' value and the economic and social advantages (supposedly) resulting from vocational training and a job in the steel industry. ${ }^{13}$ At the fair, the visitors could also experience a work site (the mine replica), see the workers in action, and talk to them in person, which in turn fostered the workers' pride in their work. In this specific setting and context, the film Columeta could be profitably employed for
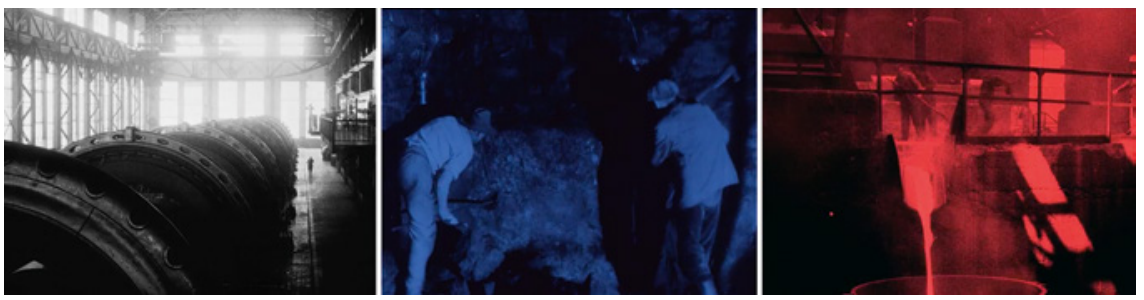

FIGURES 1.2A, 1.2B, AND 1.2C Frames from Vu Feier an Eisen, reconstructed 1997 version of Columeta (1921/22). COURTESY OF CENTRE NATIONAL DE L'AUDIOVISUEL, LUXEMBOURG, AND ARCELORMITTAL.

11 The display of human work as subordinate to the machinery was a common practice of display in steel films of the time. See Uli Jung and Wolfgang Mühl-Benninghaus, "Ästhetischer Wandel: Dokumentarische Propagandafilme," in Geschichte des dokumentarischen Films in Deutschland: Band I: Kaiserreich 1895-1918, ed. Uli Jung and Martin Loiperdinger (Stuttgart: Reclam, 2005), 432-33.

12 Early cinema has never been silent but was accompanied by commentary or music (nor was it necessarily black and white, as is shown by the tinted sequences of the film Columeta); see, for example, Germain Lacasse, Vincent Bouchard, and Gwenn Scheppler, eds., Pratiques orales du cinema: Textes choisis (Paris: L'Harmattan, 2011).

13 For the relevance of sensory experience in vocational training, see Priem and Herman, "Sensuous Geographies' in the 'Age of Steel." 
the promotion of vocational training and the industry's recruiting interests. ${ }^{14}$ In a different setting - if the audience, for instance, consisted of industrial customers - the emphasis could be put on the technological processes and the functioning of the industrial organism, which ensured the continuity of production and the high quality of the final products. Columeta was, after all, first and foremost a corporate propaganda film, produced to sell ARBED's products and popularize its distribution company, Columeta. ${ }^{15}$

The company's final products were also frequently presented through photographs published in printed brochures. Photography played a major role in the commercial presentation of product images, not least because of its quality of conveying a "naturalistic truth." This assumed and for a long time unchallenged authenticity of photographs as technically produced images made photography (and film) an ideal tool to "document" the production processes and products. ${ }^{16}$ Workers were frequently included in product images. Apart from depicting a responsible and skilled workforce, the presentation of individual workers, whose poses convey a sense of importance and pride in belonging to and being photographed for modern industry, may have had another welcome side effect for the company: The publication of these images could support both the workers' sense of belonging and the recruiting needs of the industry. ${ }^{17}$ Following Karin Priem and Frederik Herman's suggestion to take into account the physical and sensuous connectedness of humans and technology in industrial production, it could be argued that the display of workers together with their machines or products countered the Marxist perspective on industrial production as alienation and rather communicated

14 A German film that served the recruitment of workers much more explicitly was Grube Cäcilie (1917), where fictional scenes of a worker and his family framed the documentary sequences of surface mining and the production of coal briquettes. See Jung and MühlBenninghaus, "ÄsthetischerWandel," 432-33. Elevating the industry to national importance and depicting the industry's social works for the benefit of the working class in the film Columeta also supported the recruiting interests of the company. See Plein, "Beautiful Luxembourg, Steel Works and a Swimming Pool."

15 For further perspectives on the film's communicative capacities, such as the embedding of the steel industry into a wider national narrative or the company's corporate social responsibility initiatives, see Plein, "Beautiful Luxembourg, Steel Works and a Swimming Pool."

16 Photographs of industrial processes were not necessarily authentic. Insufficient lighting conditions, for example, often required manipulations such as, for example, the whitepainting of iron to make it appear as glowing hot; see Ulrich Wengenroth, "Die Fotografie als Quelle der Arbeits- und Technikgeschichte," in Tenfelde, Bilder von Krupp, 96.

17 Workers posing next to their machines had been a popular postcard motif since ca. 1900. See Hermann and Plein, "Envisioning the Industrial Present," 12-13. 
a (positive) link of man and machine, which contributed to the perception of technological innovation as a beneficial value for society. ${ }^{18}$

However, the argument made by art historian Paul Brandt in 1928 - that the "representative" industrial paintings at the turn of the century emphasized not so much human labor but the "bold inventive spirit of the engineers, who had established the industrial facilities" and that the figure of the worker only mattered as "mass and scale" - to some extent also applies to the photographic self-presentation of the Luxembourgian steel company ARBED. ${ }^{19}$ Most images published by the steel industry had the primary function of corporate promotion, with workers merely serving to indicate the scale of the industrial equipment and environment. A corporate brochure from the early 1920 contains images of the company's steel plants, production sites, and final products, sometimes with, sometimes without workers. ${ }^{20}$ An image on page 24 of the brochure shows the final product of "armature steel casting" (see fig. 1.3a). The placement of a worker - whose posture surely bespeaks a certain pride in being photographed-next to the armature illustrates the dimensions of the product. The main emphasis of the image becomes clear by comparing the brochure and the original glass plate negative (see fig. 1.3b). For the publication, the photograph was retouched: The background is darkened and harmonized; the armature itself is carefully retouched, the contours and curves are emphasized and shadowed. All alterations serve to make the presentation of
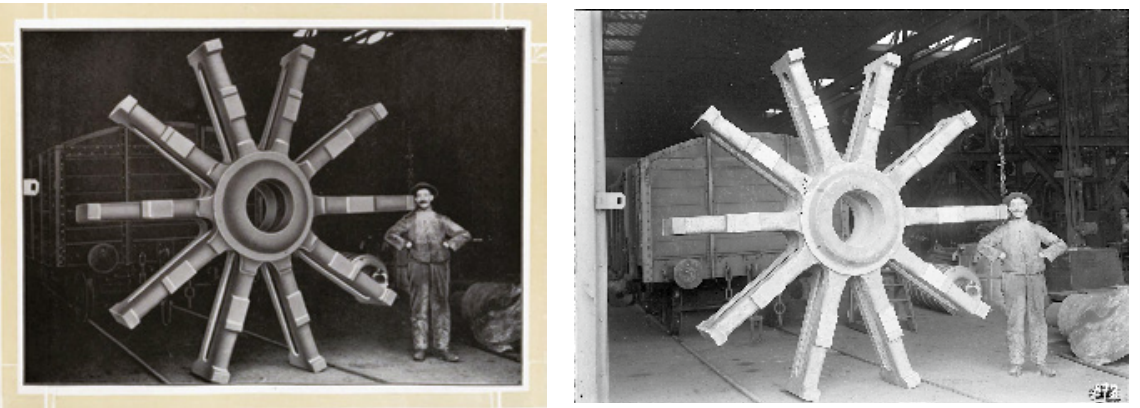

FIGURES 1.3A Spread from Columeta: Comptoir métallurgique luxembourgeois (ca. 1922), 24.

1.3в Amature steel casting." Undated. Digital positive from glass plate negative. (C) institut EMile metz. CNA COllection.

18 See Priem and Herman, "Sensuous Geographies in the 'Age of Steel."

19 Paul Brandt, Schaffende Arbeit und Bildende Kunst: Vom Mittelalter bis zur Gegenwart (Leipzig: Alfred Kröner Verlag, 1928), 332. "Mass" here is used in the sense of large numbers of people.

20 Columeta: Comptoir métallurgique luxembourgeois (Liège: Bénard, s.d. [ca. 1922]). 
the high-quality product more brilliant. Only the worker is not altered. In fact, he is the only element in the picture that still communicates the "naturalistic truth" of photography. Thus, the worker's figure accentuates the product in two ways: First, he gives an idea of the product's dimensions; and, second, he supports the image's perception as an "authentic" photograph, even though the image has been extensively retouched. Nevertheless, the presence of the worker - and the absence of any production machinery, whether by accident or design - also reveals the role that human labor plays in the production process. The actual visibility of the worker is an acknowledgment of the worker's importance and adds to his self-image, pride, and sense of belonging.

\section{The Worker's Body as Representation of the Industry}

A much more explicit acknowledgment of the worker's importance and value was communicated in representative works of art, where the worker's body was employed in allegorical depictions of the industry. At the 1937 World Fair in Paris, where the steel industry played a key role in Luxembourg's selfpresentation, a wall frieze by Jean Schaack, illustrating the country's regions, sports activities, touristic attractions, and economic sectors, such as agriculture and industry, decorated the restaurant of the Luxembourg Pavilion. ${ }^{21}$ The (steel) industry is represented by elements of the industrial organism: stylized blast furnaces, hoisting cranes, billowing steam, red hot liquid iron, a large gearwheel, and the dominant figure of the worker (see fig. 1.4). He is featured as a masculine and proud figure, holding a hammer. While the worker is part of an industrial environment, he is not shown during the act of working, but as the heroic master of the scene. The worker's strong physique obscures the negative effects of industrial work, such as exhaustion, weakness, and physical and mental fatigue, and instead communicates the worker's strength and pride. It is a heroic idealization of the worker; mastering both the machinery and the elements, he is presented as a representative of the entire industrial sector.

Another heroic version of the worker was prominently displayed in a series of bas-reliefs by Auguste Trémont on the exterior wall of the Luxembourg pavilion. Besides several scenes depicting industrial work, three allegorical personifications of the industry were positioned to the left of the entrance,

21 See Jean-Luc Mousset and Ulrike Degen, "Paris 1937," in Un petit parmi les grands: Le Luxembourg aux Expositions universelles de Londre à Shanghai (1851-2010), ed. JeanLuc Mousset and Ulrike Degen (Luxembourg: Musée national d'histoire et d'art, 2010), 189-205; Plein, "Beautiful Luxembourg, Steel Works, and a Swimming Pool." 


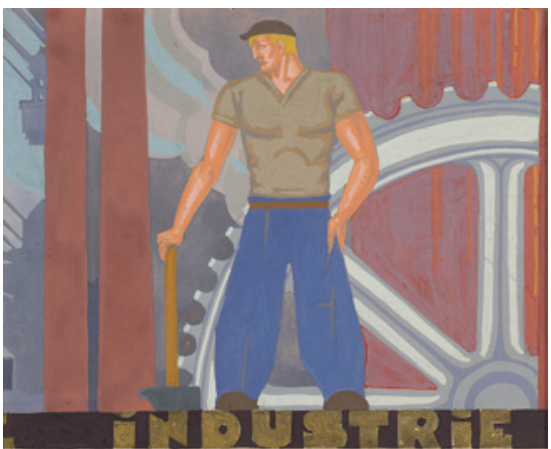

FIGURE 1.4

Design by Jean Schaack for an element of the frieze of the Luxembourg Pavilion restaurant at the Paris World Exhibition, 1937. Gouache on paper. COURTESY OF MUSÉE NATIONAL D'HISTOIRE ET D'ART, LUXEMBOURG.

facing personifications of agriculture to the door's right. Four such personifications were reprinted in the catalogue (see fig. 1.5). ${ }^{22}$ While agriculture is presented as a graceful female figure (in the tradition of female allegories), industry is personified by muscular and self-assured male figures. Drawing on the pictorial tradition of the heroic worker as blacksmith, which Schaack had also employed for the allegorical wall frieze, Trémont too used the convention of the heroic worker but divided the field of industrial work into the distinct trades involved in the process of steel-making. ${ }^{23}$ The steel industry is represented by three figures whose clothes and attributes signify the miner, the mill train worker, and the smelter, communicating the variety and value of different skills and trades within the industrial organism. Placed outside an industrial environment (and omitting any references to the risks and dangers of industrial work), the reliefs present the industrial workers' male bodies as the embodiment of productivity, power, and strength. ${ }^{24}$ By literally carving the (skilled) worker in stone, the reliefs communicated his importance and value for the industry and thus for the nation's wealth and prosperity to the visitors of the World Fair and - through publication in the catalogue and photographs in the illustrated press - to a broader Luxembourg audience.

22 Le Grand Duché de Luxembourg à l'Exposition Internationale de Paris 1937 (Luxembourg: Commissariat général du gouvernement luxembourgeois, 1937). Photographs of the pavilion were also published in the illustrated magazine $A-Z$ : Luxemburger illustrierte Wochenschrift, August 8, 1937, 4-5.

23 The pictorial tradition of the blacksmith who is fighting and domesticating the elements is drawing on the Greek and Roman myths of Hephaistos and Vulcan, respectively. See, for instance, Klaus Türk and Manfred Jablonski, "Hüttenarbeiterskulpturen im öffentlichen Raum des 19. und 20. Jahrhunderts," in 150 Jahre Stahlinstitut VDEh 1860-2010, ed. Helmut Maier, Manfred Rasch, and Andreas Zilt (Essen: Klartext Verlag, 2010), 576; see also Klaus Türk, Bilder der Arbeit: Eine ikonografische Anthologie (Wiesbaden: VS Verlag für Sozialwissenschaften, 2000), 78-81.

24 See also Türk and Jablonski, "Hüttenarbeiterskulpturen im öffentlichen Raum des 19. und 20. Jahrhunderts," 576 . 


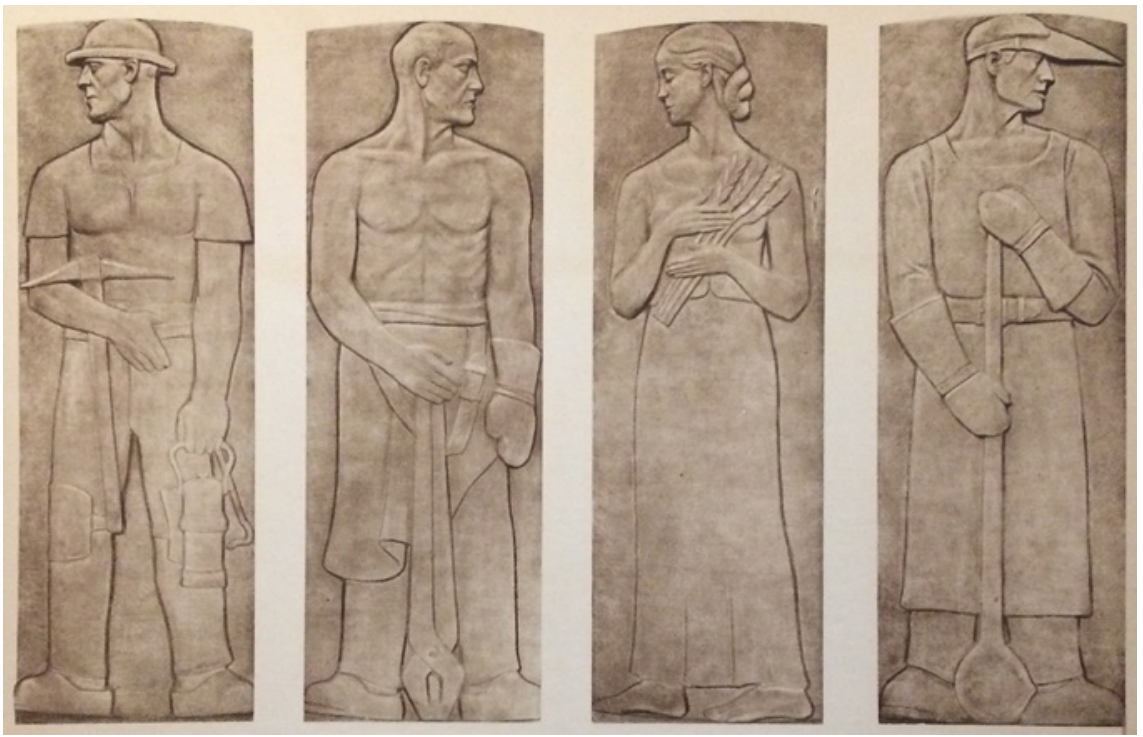

FIGURE 1.5 Worker reliefs by Auguste Trémont and Lucien Wercollier on the Luxembourg Pavilion, Paris World Exhibition, 1937. Reprinted from Le Grand Duché de Luxembourg à l'Exposition Internationale de Paris 1937, 21.

Auguste Trémont had used the figure of the industrial worker in representative artworks before and had, in fact, helped shape the image of the industrial worker since World War I. Trémont had interrupted his education at the École national des beaux arts in Paris to spend the war years in Luxembourg, where he was employed as a technical draftsman at the steelworks in Dudelange. ${ }^{25}$ In his leisure time, he was allowed to take sketches of the plant's interior and of the workers, which he frequently re-used for other assignments in later years. Trémont had already exhibited paintings of industrial workers in the 1916 Luxembourg Salon du Cercle Artistique. ${ }^{26}$ His painting La coulée de fonte (Iron casting) shows a pair of steelworkers at work (see fig. 1.6). While the title refers to the depicted production process, it is the workers who are at the center of the image and highlighted by the white steam in the background. In the painting, it is not the machinery but first and foremost the physical strength and the concentrated work of the men that is presented as central to the process of iron making.

25 See Georges Schmitt, Auguste Trémont (Luxembourg: Section des Arts et Lettres de l'Institut Grand-Ducal, 1980), 9-11.

26 In 1916, Trémont had also created a triptych with motifs of industrial work(ers) for the mess hall at the Dudelange plant; see ibid. 


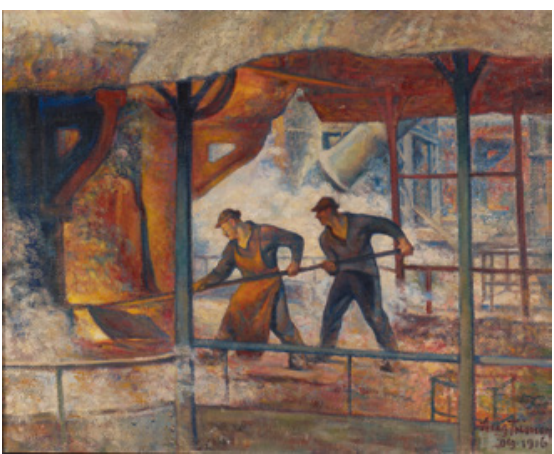

FIGURE 1.6

Auguste Trémont, La coulée de fonte (Iron casting), 1916. Oil on canvas. 61 x $75 \mathrm{~cm}$. COURTESY OF MUSÉE NATIONAL

D'HISTOIRE ET D'ART, LUXEMBOURG.

Again drawing on his earlier sketches, Trémont also decorated the entrance of the Luxembourg Pavilion at the 1935 World Fair in Brussels. Here, the industrial worker was depicted in a very different manner: A pillar shows a multitude of miners and steel workers who are performing their tasks in an industrial landscape, while an outsized worker's figure dominates the scene. In the pose of Rodin's The Thinker, he is depicted as an individualized and thoughtful representative of the working class and the industry (see figs. 1.7a, 1.7b).

The worker with the impressive physique - who we know today was the steel worker Mathias Gaasch from Dudelange—seems to have been Trémont's favorite model. He is depicted in many of Trémont's artworks, which were used in a variety of media - on a book cover, on ARBED's certificates of honor, and on the one- and two-franc coins that were in use between 1924 and 1991-thus circulating the image of the heroic worker in Luxembourg for decades. ${ }^{27} \mathrm{Be}-$ sides his physique, Mathias Gaasch thus provided a familiar face to a wide variety of visual representations of industrial work. The display of individual workers in art offered a space for recognition and, more importantly, for subjective identification with the worker.

While neither drawing, painting, nor sculpture can be considered mass media, they were part of the extensive circulation of the motif of the industrial worker in Luxembourg - through coins, book illustrations, or photographs in newspaper articles and brochures. Although they lacked photography's "naturalistic truth," painting and sculpture communicated an increased esteem for industrial work in Luxembourg society. To a Luxembourg audience, all of these

27 See René Link, "La sidérurgie sur timbres et billets de banque/Steelmaking Depicted on Postage Stamps and Banknotes," in La sidérurgie luxembourgoise: Un siècle d'histoire et d'innovation/Steelmaking in Luxembourg: A Century of History and Innovation, ed. ArcelorMittal (Luxembourg: ArcelorMittal, 2011), 29-31. The book cover, where the figure is presented in the context of war, is reprinted in Auguste Trémont:Der Künstler, der die Tiere liebte, ed. Nic Weber (Luxemburg: Éd. des Cahiers luxembourgeois, 1993), 127. 

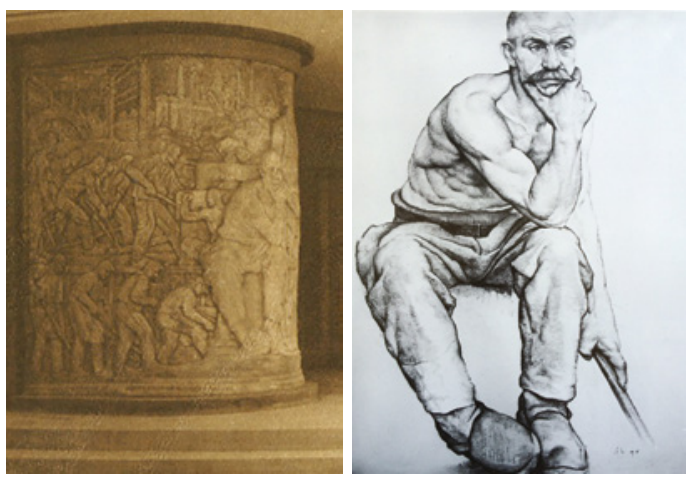

FIGURES 1.7A Detail of a photograph depicting the entrance to the Luxembourg Pavilion at the Brussels World Exhibition, 1935. Reprinted from Le Grand-Duché de Luxembourg à l'Exposition Internationale de Paris 1937, 207.

1.7B Drawing by Auguste Trémont, ca. 1916. 75 x $55 \mathrm{~cm}$. Reprinted from Schmitt, Auguste Trémont, 72.

visual representations demonstrated the industrial worker's (inter-)national appreciation and thus enhanced the reputation of the entire working class. The circulation of heroic images of the worker in a variety of media contributed to the public discourse on industrial work, communicating and acknowledging the workers' self-confidence and fostering the belief in economic progress for the benefit of all.

\section{4 Proletarian Perspectives on the Worker's Body and the Industrial Organism}

The depictions from the mid-193os also testify to the enhanced status of industrial work at a time when the labor unions were able to achieve unprecedented success and recognition. In Luxembourg, the labor movement evolved rather late; the mining and steel unions were founded only during the First World War. ${ }^{28}$ After an unsuccessful strike in 1921 and a subsequent decline in membership, it took several years for the unions to recover and gain (new) force. ${ }^{29}$ During the Great Depression of the 1930s, a wage increase and the union's

28 See Fréderik Krier et al., eds., 100 Joer fräi Gewerkschaften 1916-2016 (Esch-sur-Alzette: oGBL/Éditions Le Phare, 2016), published on the occasion of the centenary of the free labor unions in Luxembourg.

29 See Denis Scuto, "De la grande grève de mars 1929 à l'intégration dans la nation: Les syndicats libres dans l'entre-deux-guerres," in Krier et al., 10o Joer fräi Gewerkschaften, 71. 
official political recognition were the two main objectives of the unions' struggle. ${ }^{30}$ In 1936, one year before the Paris World Fair, a mass demonstration of labor unions forced the government to install a Conseil National du Travail (National Council of Work), where representatives of employers and unions were appointed to find solutions for labor disputes under the auspices of the government, eventually leading to the first collective bargaining agreements in Luxembourg. ${ }^{31}$

The call for workers' political participation and unity also found expression in the visual media that were used to highlight the working conditions and the economic insecurity of the working class as well as the need to close ranks and show a united front. In the early 1930s, the illustrated book Der tägliche Weg (The daily way [to work]) provided a proletarian perspective on workers' lives during the crisis. ${ }^{32}$ The book contained linocuts by the artist Albert Kaiser, a former mining and steel worker who was active in the labor union's educational initiatives and hence clearly fired by a political agenda. Presenting the flipside of industrial work, Kaiser's work took a clear stand and illustrated the need for the political participation of the working class. Depicting the workers' precarious living and working conditions, Kaiser often contrasted them with the living conditions of the rich or pointed to the causes of the workers' plight. Both the text and the images in Der tägliche Weg can be understood as a plea to the labor movement to achieve unity in order to gain political weight and power. ${ }^{33}$

One of his linocuts presents workers at the site of production (see fig. 1.8). In the lower section, two workers carry out their tasks on an assembly line. They are isolated from each other and literally chained to their monotonous activity. The clock determines the pace and the rhythm of work. A smaller figure inside a gearwheel that is directly linked to the clock is running like in a treadwheel. The transmission belts physically limit the workers' freedom of movement, their hands are literally tied to the horizontal rods and thus make the worker a part of the machinery; the postures of the workers express fatigue and resignation. The image communicates the negative, structural effects of the capitalist system on the worker, his body and his soul. The worker is presented as a

30 Ibid.

31 Ibid., 75 .

32 See Der tägliche Weg: Reportage aus Arbeiterzügen von Ex. mit Linolschnitten von A. K. (Esch-sur-Alzette: Luxemburger Genossenschaftsdruckerei, 1932). Before the book's publication, many of the linocuts were published in the leftist newspaper Escher Tageblatt; see Ira Plein, "Der tägliche Weg zur Schicht': Aspekte zur proletarischen Kunst Albert Kaisers in der Zwischenkriegszeit," in Krier et al., 10o Joer fräi Gewerkschaften, 93.

Ibid., 83-97. 


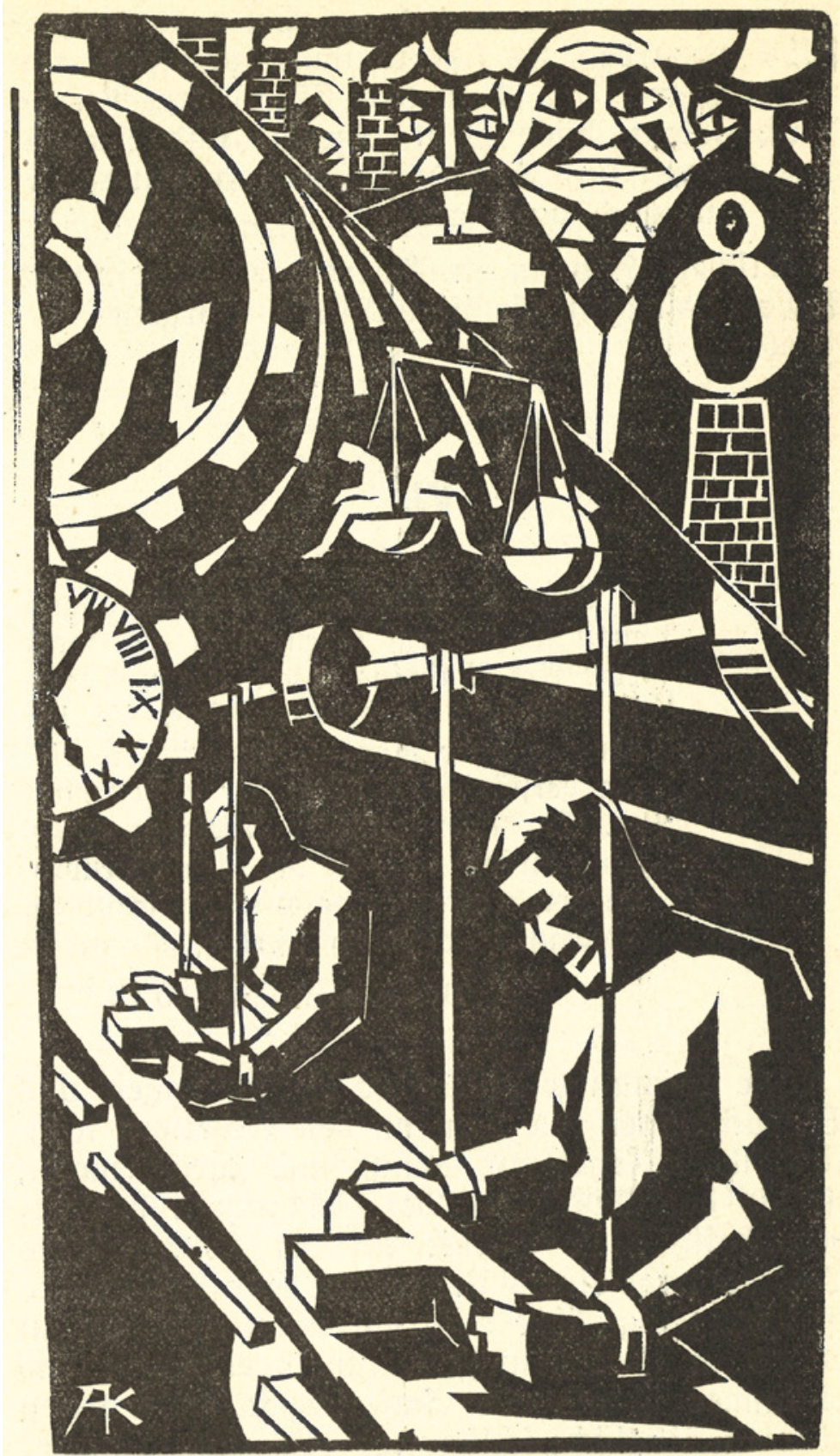

FIGURE 1.8 Linocut by Albert Kaiser. Reprinted from Der tägliche Weg (1932), 28. 
small cog in the wheel of industry and thus - as postulated by Marx - part of the capitalists' property. Here, too, the worker is part of the industrial organism, but the image does not convey pride and a sense of belonging. Rather, the workers are pictured in chains and subordinated to the industrial machinery that is part of the capitalist economic system. The physique of the workers is executed in a particularly crude way: the faces look like masks and the hands like robotic tools. The class differences are visualized by the antagonistic display of the body of "the capitalist." The bulky physique of the entrepreneur in the upper section, which is contrasted to the fatigued and chained bodies of the workers, affirms the class divide. Seen from this politically motivated proletarian perspective, being a part of the industrial organism means subordination and the loss of humanity. Preventing any kind of identification with the depicted individuals, the highly stylized and anonymized figures of the workers instead support their perception as representatives of the working class. Nevertheless, these works, too, claim authenticity, as they present an insider's perspective on the reality of industrial working conditions in the capitalist system. This very different perspective on the societal "truth" countered the images of workers as being part, or representative, of a healthy industrial organism in order to visualize and bring forward an argument for political action.

A proletarian standpoint was also expressed in the medium of photographyeven using the modernist technique of photomontage, which is explicitly pointing up the deliberate (re)construction of reality. ${ }^{34}$ In January 1934, the illustrated magazine $A-Z$ published a full-page photomontage depicting a worker outside of the factory, reading a newspaper on the streets in a bourgeois urban setting (see fig. 1.9). The blast furnaces are present even here; they are softly mounted into the background, but become more distinctly visible in the sky, from where they dominate the scene. The fact that no smoke comes out of the chimneys points to the economic crisis, as does the title of the photomontage: "Arbeitslos... wie lange noch...?" (Unemployed... for how much longer...?). The question reflects the worker's feeling of helplessness, his inability to actively change his situation. He can only wait and check the newspaper for job advertisements. This scene does not present the worker as part of the larger industrial organism, nor as a heroic industrial worker. Quite the opposite. Here,

34 The role of photography for proletarian (self-)presentation begs further research. A catalogue of the National Photography Exhibition of 1935, organized by the Union Photographique Esch-sur-Alzette, lists titles that indicate the display of industrial motifs, ranging from factory views to clearly defined processes of steel-making. However, the majority of the exhibited photographs carried titles that imply rather bourgeois motifs and topics (for example, idyllic landscapes, flowers or cultural heritage sights); see zième Salon nationale de la photographie (Esch-sur-Alzette: Union Photographique, 1935). 


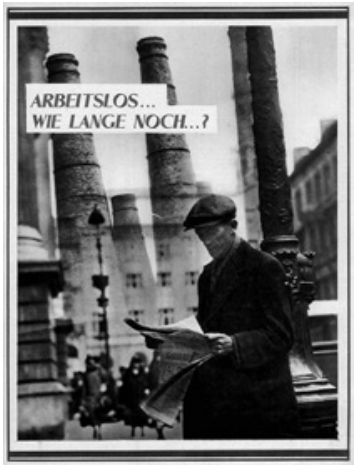

FIGURE 1.9

"Arbeitslos... wie lange noch...?" (Unemployed... for how much longer ...?). Photomontage. Reprinted from A-Z: Luxemburger illustrierte Wochenschrift, January 7, 1934, 5 .

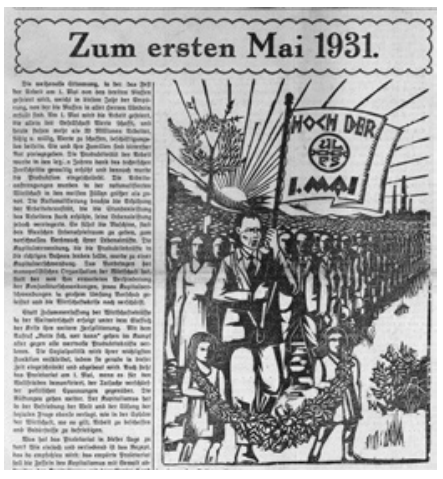

FIGURE 1.10

Linocut by Albert Kaiser. Reprinted from Escher Tageblatt, May 1, 1931, cover page.

the viewer sees an uneasy and lean worker who has been expelled from the industrial organism. The image does not explicitly name the problems that the worker is facing, but a working-class reader would know.

The need to close ranks and fight for the interests of the working class was, of course, a main message of the labor movement. For the May 1, 1931, issue of the leftist newspaper Escher Tageblatt, Albert Kaiser created a linocut that depicts the labor movement as a massive but peaceful force (see fig. 1.10). A huge number of workers is marching under the banner of the free unions, guided by a (suit- and tie-wearing) leader. The industrial site is visible only in the far background. The masses of workers (and employees) leave the plant to celebrate Labor Day. The working class is represented not by a single person or a few stylized figures but by anonymous bodies of workers. In addition, the linocut shows not only male workers but also children and women and makes no distinction between factory and office workers. To inspire workers and employees to action - in the interests of and for the benefit of the working class as a whole - anonymous masses of stylized bodies were used to create a sense of community and to illustrate (and advocate) the strength of a mass movement. 
Images of industrial work(ers) were deployed by various actors in interwar Luxembourg society. The different images testify to a lively debate on industrial work at the economic, social, and political levels. Looking at visual representations of industrial work(ers) as contributions to a public discourse provides further evidence of the competing political positions at the time but also opens up new perspectives on the communicative capacity of images and media presentations in Luxembourg. The variety of visual representations in different media and imaging technologies all contributed to a public discourse on industrial work, drawing on capitalist, philanthropist, nationalist, and Marxist ideas and metaphors.

According to Pierre Bourdieu, positions are continuously rearranged within a dynamic social space as a result of the struggle for distinction and participation. ${ }^{35}$ In the case of images, too, the question of power and societal control over the discourse is essential, since, according to Michel Foucault, "in every society, the production of discourse is at once controlled, selected, organised and redistributed." ${ }^{36}$ Images show certain aspects and exclude others, in order to emphasize a certain topic or perspective, or to propagate a certain mindset. Sociologist Klaus Türk has stated that images of work inevitably have a political tendency, as depictions of work always comment on contemporary conceptions of work-either interpreting, reflecting on, white-washing, supporting or contradicting the prevailing views of the time. ${ }^{37}$ As such, images of work are reflections and co-producers of social constructions and "politics of truth" that express the arguments and agendas of the artist, the client, or the publisher. ${ }^{38}$ Authorship, technology, and the context of publication or display greatly influence the value and power of visual "argumentation" - both in terms of the addressed audience(s) and the broader public discourse. ${ }^{39}$ Photography

35 See Pierre Bourdieu, "The Social Space and the Genesis of Groups," Theory and Society 14, no. 6. (1985): 723-44.

36 Michel Foucault, "The Order of Discourse," in Untying the Text: A Poststructuralist Reader, ed. Robert Young (Boston: Routledge, 1981), 52 .

37 Klaus Türk, "Arbeit in der bildenden Kunst," in Anthropologie der Arbeit, ed. Ulrich Bröckling and Eva Horn (Tübingen: Gunter Narr Verlag, 2002), 37.

38 Ibid. Klaus Türk has done fundamental research on images of work, see Türk, Bilder der Arbeit.

39 See, for example, Abigail Solomon-Godeau, "Who Is Speaking Thus? Some Questions about Documentary Photography," in Photography at the Dock: Essays on Photographic History, Institutions, and Practises (Minneapolis: University of Minnesota Press, 1991), $169-83$. 
must capture "the necessarily real thing which has been placed before the lens, ${ }^{40}$ while painting, the graphic arts, and sculpture are widely understood as a willed construction of the motif and as a synthesis of the author's subjective perspective, which is influenced by his/her cultural, social, and intellectual background.$^{41}$ Yet as much as the fine arts can claim authenticity and validity for being a (condensed) representation of the truth, photography too is capable of representing ideas and conceptions beyond the depicted motif.42 Roland Barthes has pointed both to the "truth of the image, the reality of its origin," and to its potential for deception and delusion by the systematic arrangement and embedding of photographs into specific contexts. ${ }^{43}$

As the presented examples show, authorship matters, but the technologies and contexts of display are just as important. The medium of photography, which was considered state of the art for truthful "documentation," left room for different presentations and perceptions of that which was depicted. As part of the steel industry's self-representation, which was accomplished predominantly through photography, the worker's figure served different objectives, which ranged from promoting the industry's commercial products to serving its recruitment purposes. Photograph captions or film commentaries, which could be adapted to different audiences, determined the images' meaning and reception. Presenting the heroic figure of the worker as a motif in the prestigious fine arts, such as painting or sculpture, contributed to enhancing the social recognition and perception of the worker. The context of display, too, gave meaning to the motifs: At the World Fairs, for example, it elevated the industry, the industrial worker, and thus the working class to national importance in times of increasing political participation. Before that, the political left in Luxembourg had presented proletarian perspectives on industrial work(ers) in the popular media; by pointing to the physical and psychological hazards of industrial production and promoting solidarity and collective political action,

40 Roland Barthes, Camera Lucida: Reflections on Photography, trans. Richard Howard (New York: Hill and Wang, 1981), 76 .

41 See Ernst H. Gombrich, Art and Illusion (New York: Phaidon Press, 2012), 55-78.

42 See Türk, "Arbeit in der bildenden Kunst," 35. Daston and Galison have shown that there is no such thing as objectivity in any media or technique, and that the concept of objectivity is changing over time; see Lorraine Daston and Peter Gallison, Objectivity (New York: Zone Books, 2007).

43 Barthes, Camera Lucida, 77-79, quotation on 77. For the influence of context and forms of display on the perception of photographs, see also his article on the exhibition "The Family of Man": Roland Barthes, "The Great Family of Man," in Mythologies, trans. Annette Lavers (London: Vintage, 2000), 100-102. 
these images were intended to support the labor movement's fight for political influence and participation.

The diversity of images of industrial workers-depicted as masses, as means to show the scale of industrial products or machinery, as machine-like robots, or (often simultaneously) as representatives or metaphors for an abstract concept-reflected, and reflected on, the conflicting perspectives on the societal status of industrial work in interwar Luxembourg. The diverging images, genres, and media interacted and referred to each other, building on or contradicting other views circulating at the time. As the art historian Ernst Gombrich has shown, the perception of images is not least determined by the mindsets and expectations of the viewers. ${ }^{44}$ It is, in fact, this very struggle for people's mindsets that can be traced by looking at the visual media in Luxembourg. Each group employed the figure of the industrial worker for its own ends and drafted it into the service of its ideas and perspectives on industrial work. Suggesting specific ways of seeing, the images contributed to the perception and meaning-making of industrial work(ers) at the time and, from today's perspective, are evidence of a heterogeneous and competitive debate on the working class in interwar Luxembourg.

\section{Sources and Bibliography}

\section{Primary Sources}

"Ausstellung der Stadt Esch-Alz." Luxemburger Wort, September 8, 1923.

Columeta: Comptoir métallurgique luxembourgeois. Liège: Bénard, s.d. [ca. 1922].

"Der Luxemburger Pavillon auf der Internationalen Ausstellung in Paris." A-Z: Luxemburger illustrierte Wochenschrift, August 8, 1937, 4-5.

Der tägliche Weg: Reportage aus Arbeiterzügen von Ex. mit Linoschnitten von A. K. Eschsur-Alzette: Luxemburger Genossenschaftsdruckerei, 1932.

"Die National-Ausstellung in Esch an der Alzette." Obermosel-Zeitung, September 11, $1923,1-2$.

44 According to Gombrich, there are certain learned conventions-or mindsets - that define one's subjective perception and the representation of reality. Gombrich argues that human beings, when looking at images, are constantly searching for meaning and that perceptions are continually "integrated" until they make sense. Images therefore can be understood as visual suggestions for meaning-making, which build on the existing mindsets of the viewers and adapt to their subjective expectations. See Gombrich, Art and Illusion, 55-78; Ernst H. Gombrich, "Bild und Kode: Die Rolle der Konvention in der bildlichen Darstellung und Wahrnehmung," in Bild und Auge: Neue Studien zur Psychologie der bildlichen Darstellung (Stuttgart: Klett-Cotta, 1984), 285. 
"Exposition nationale des arts et métiers, du commerce et du travail." Escher Tageblatt, September 12, 1923, 1.

Exposition nationale des arts et métiers, du commerce et du travail à Esch-sur-Alzette du 8 au 18 septembre 1923. Esch-sur-Alzette: Société cooperative, 1923.

Le Grand Duché de Luxembourg à l'Exposition Internationale de Paris 1937. Luxembourg: Commissariat général du gouvernement luxembourgeois, 1937.

zième Salon nationale de la photographie. Esch-sur-Alzette: Union Photographique, 1935 .

“Über den Abbau der im Boden lagernden nutzbaren Mineralien." Tageblatt, September $22,1923,4-5$.

\section{Bibliography}

Arida, Persio. "Soziale Differenzierung und Wirtschaftstheorie." In Soziale Differenzierung: Zur Geschichte einer Idee, edited by Niklas Luhman, 68-95. Opladen: Westdeutscher Verlag, 1985.

Barthel, Charles. “'COLUMETA' ('Vu Feier an Eisen'): L'aventure du premier film publicitaire de l'Arbed." Hemecht 50, no. 2 (1998): 177-206.

Barthes, Roland. Camera Lucida: Reflections on Photography. Translated by Richard Howard. New York: Hill and Wang, 1981.

Barthes, Roland. “The Great Family of Man.” In Mythologies. Selected and translated by Annette Lavers, 100-102. London: Vintage, 2000.

Bourdieu, Pierre. "The Social Space and the Genesis of Groups." Theory and Society 14, no. 6. (1985): 723-44.

Brandt, Paul. Schaffende Arbeit und Bildende Kunst: Vom Mittelalter bis zur Gegenwart. Leipzig: Alfred Kröner Verlag, 1928.

Daston, Lorraine, and Peter Gallison. Objectivity. New York: Zone Books, 2007.

Foucault, Michel. "The Order of Discourse." In Untying the Text: A Poststructuralist Reader, edited by Robert Young, 51-78. Boston: Routledge, 1981.

Gombrich, Ernst H. Art and Illusion. New York City: Phaidon Press, 2002.

Gombrich, Ernst H. "Bild und Kode: Die Rolle der Konvention in der bildlichen Darstellung und Wahrnehmung." In Bild und Auge: Neue Studien zur Psychologie der bildlichen Darstellung. 274-293. Stuttgart: Klett-Cotta, 1984.

Herman, Frederik. "Forging Harmony in the Social Organism: Industry and the Power of Psychometric Techniques." History of Education 43, no. 5 (2014): 592-614.

Hermann, Frederik, and Ira Plein. "Envisioning the Industrial Present: Pathways of Cultural Learning in Luxembourg (1880s-1920s)." Paedagogica Historica (2016):1-17. http://dx.doi.org/10.1080/00309230.2016.1259243.

Herman, Frederik, Karin Priem, and Geert Thyssen. "Körper_Maschinen? Die Verschmelzung von Mensch und Technik in Pädagogik, Industrie und Wissenschaft." Jahrbuch für Historische Bildungsforschung 20 (2015): 47-75. 
Jung, Uli, and Wolfgang Mühl-Benninghaus. "Ästhetischer Wandel: Dokumentarische Propagandafilme." In Geschichte des dokumentarischen Films in Deutschland: Band I: Kaiserreich 1895-1918, edited by Uli Jung and Martin Loiperdinger, 429-53. Stuttgart: Reclam, 2005.

Kahn, Fritz. Das Leben des Menschen. 5 vols. Stuttgart: Franckh'sche Verlagshandlung, 1926.

Kift, Dagmar. “Die schaffende Menschenkraft bewirtschaften': Zur Schulung und Erziehung von Arbeiter- und Werkskörpern im Ruhrbergbau der 1920er Jahre." In Kontrollierte Arbeit - disziplinierte Körper? Zur Sozial- und Kulturgeschichte der Industriearbeit im 19. und 20. Jahrhundert, edited by Lars Bluma and Karsten Uhl, 73-106. Bielefeld: transcript Verlag, 2012.

Krier, Fréderik, Jacques Maas, Arnaud Sauer, and Denis Scuto, eds. 100 Joer fräi Gewerkschaften 1916-2016. Esch-sur-Alzette: OGBL/Éditions Le Phare, 2016.

Lacasse, Germain, Vincent Bouchard, and Gwenn Scheppler, eds. Pratiques orales $d u$ cinema: Textes choisis. Paris: L'Harmattan, 2011.

Link, René. "La sidérurgie sur timbres et billets de banque/Steelmaking Depicted on Postage Stamps and Banknotes." In La sidérurgie luxembourgoise: Un siècle d'histoire et d'innovation/Steelmaking in Luxembourg: A Century of History and Innovation, edited by Arcelor Mittal, 29-31. Luxembourg: ArcelorMittal, 2011.

Lorang, Antoinette. L'image sociale de l'Arbed à travers les collections du Fonds du logement. Luxembourg: Le Fonds pour le développement du logement, 2009.

Lüdtke, Alf. "Gesichter der Belegschaft: Portraits der Arbeit." In Bilder von Krupp: Fotografie und Geschichte im Industriezeitalter, edited by Klaus Tenfelde, 67-87. Munich: C. H. Beck, 1994.

Mousset, Jean-Luc, and Ulrike Degen. "Paris 1937." In Un petit parmi les grands: Le Luxembourg aux Expositions universelles de Londre à Shanghai (1851-2010), edited by Jean-Luc Mousset and Ulrike Degen, 189-205. Luxembourg: Musée national d'histoire et d'art, 2010.

Plein, Ira. "Beautiful Luxembourg, Steel Works, and a Swimming Pool: The Corporate Film COLUMETA and the Formation of a Corporate, and National, Image." In Films That Work Harder: The Global Circulations of Industrial Cinema, edited by Vinzenz Hediger, Florian Hoof, and Yvonne Zimmermann. Amsterdam: Amsterdam University Press, forthcoming.

Plein, Ira. “'Der tägliche Weg zur Schicht': Aspekte zur proletarischen Kunst Albert Kaisers in der Zwischenkriegszeit." In Krier et al., 10o Joer fräi Gewerkschaften, 83-97.

Priem, Karin, and Frederik Herman. 'Sensuous Geographies' in the 'Age of Steel': Educating Future Workers' Bodies in Time and Space (1900-1940)." In this volume.

Schmitt, Georges. Auguste Trémont. Luxembourg: Section des Arts et Lettres de l'Institut Grand-Ducal, 1980. 
Scuto, Denis. "De la grande grève de mars 1929 à l'intégration dans la nation: Les syndicats libres dans l'entre-deux-guerres." In Krier et al., 10o Joer fräi Gewerkschaften, $47-81$.

Solomon-Godeau, Abigail. "Who Is Speaking Thus? Some Questions about Documentary Photography." In Photography at the Dock: Essays on Photographic History, Institutions, and Practises, 169-83. Minneapolis: University of Minnesota Press, 1991.

Stercken, Angela. "Die Gesolei als Schaubild des Körpers: Sektionen, Überblick." In Kunst, Sport und Körper | GeSoLei 1926-2002, edited by Hans Körner and Angela Stercken, 19-24. Ostfildern: Hatje Cantz Verlag, 2002.

Tenfelde, Klaus, ed. Bilder von Krupp: Fotografie und Geschichte im Industriezeitalter. Munich: C.H. Beck, 1994.

Türk, Klaus. "Arbeit in der bildenden Kunst." In Anthropologie der Arbeit, edited by Ulrich Bröckling and Eva Horn, 35-77. Tübingen: Gunter Narr Verlag, 2002.

Türk, Klaus. Bilder der Arbeit: Eine ikonografische Anthologie. Wiesbaden: VS Verlag für Sozialwissenschaften, 2000.

Türk, Klaus, and Manfred Jablonski. "Hüttenarbeiterskulpturen im öffentlichen Raum des 19. und 20. Jahrhunderts." In 150 Jahre Stahlinstitut VDEh 1860-2010, edited by Helmut Maier, Manfred Rasch, and Andreas Zilt, 575-611. Essen: Klartext Verlag, 2010.

Weber, Nic, ed. Auguste Trémont: Der Künstler, der die Tiere liebte. Luxembourg: Éditions des Cahiers Luxembourgeois, 1993.

Wengenroth, Ulrich. “Die Fotografie als Quelle der Arbeits- und Technikgeschichte." In Tenfelde, Bilder von Krupp, 98-104. 